\title{
PENGEMBANGAN LEMBAR KERJA SISWA PADA MATERI SEGITIGA DENGAN PENDEKATAN REALISTIC MATHEMATICS EDUCATION SISWA KELAS VII MTS MASMUR PEKANBARU
}

\author{
Reni Marthalena \\ Pasca Sarjana Pendidikan Matematika Universitas Riau \\ Email : renimarthalena93@gmail.com
}

\begin{abstract}
Abstrak. Tujuan dari penelitian ini adalah untuk mengembangkan lembar kerja siswa menggunakan pendekatan matematika realistis pada materi segitiga yang valid dan praktis. Dalam hal ini, penulis mengikuti prosedur penelitian dan pengembangan yang secara keseluruhan, penulis mulai dari potensi dan masalah, pengumpulan data, desain produk, validasi desain, revisi desain, penggunaan / aplikasi uji coba, dan yang terakhir revisi produk. Potensi masalah didapatkan dari wawancara dan observasi yang dilakukan di MTs Masmur Pekanbaru pada bulan September 2014 hingga Januari 2015. Kemudian, pengumpulan data tentang kurikulum yang digunakan, data kompetensi dasar dan indikator untuk bahan segitiga. Setelah merancang produk, kemudian, produk diberikan kepada validator sebagai ahli, untuk menilai hasil produk yang baru saja dibuat. Setelah divalidasi, kemudian harus dilakukan revisi produk, setelah itu, diizinkan untuk melakukan uji coba penggunaan / aplikasi yang dilakukan di Mts Masmur Pekanbaru. Dalam uji coba, penulis juga memberikan kuesioner kepada siswa, guru dan pengamat untuk melihat efisiensi produk LKS yang digunakan dalam proses belajar mengajar. Kuesioner yang diberikan adalah tentang respon siswa, respon guru dan kuesioner implementasi. Dimana validitas nilai LKS sebesar 78,41 dengan kategori cukup valid dan hasil kepraktisan LKS selama empat pertemuan diperoleh nilai kepraktisan sebesar 86,1 untuk kategori sangat praktis. Jumlah siswa yang diamati adalah 23 siswa. Jadi, disimpulkan bahwa produk LKS pada bahan segitiga menggunakan pendekatan RME adalah valid dan praktis untuk digunakan oleh siswa kelas tujuh MTs Masmur Pekanbaru.
\end{abstract}

Kata Kunci: Realistic Mathematics Education (RME) , Lembar Kerja Siswa, Pengembangan

\section{PENDAHULUAN}

Bidang studi matematika diperlukan untuk proses perhitungan dan proses berpikir yang sangat dibutuhkan orang dalam menyelesaikan berbagai masalah (Susanto, 2012a). Secara khusus, tujuan pembelajaran matematika di sekolah, sebagaimana yang disajikan oleh Depdiknas (Susanto, 2012b) adalah sebagai berikut : (1) Memahami konsep matematika, menjelaskan keterkaitan antarkonsep, dan mengaplikasikan konsep atau algoritma, (2) Menggunakan penalaran pada pola dan sifat, melakukan manipulasi matematika dalam generalisasi, menyusun bukti, atau menjelaskan gagasan dan pernyataan matematika, (3) Memecahkan masalah yang meliputi kemampuan memahami masalah, merancang model matematika, menyelesaikan model, dan menafsir solusi yang diperoleh, (4) Mengkomunikasikan gagasan dengan simbol, tabel, diagram, atau media lain untuk menjelaskan keadaan atau masalah, (5) Memiliki sikap menghargai penggunaan matematika dalam kehidupan sehari-hari. pengembangan kurikulum.

Menurut Supartono (Misdalina et al, 2009) Kenyataan yang masih sering ditemui adalah masih banyak siswa yang mengalami kesulitan dalam mempelajari matematika.

Pembelajaran matematika hendaknya memberikan kesempatan yang luas pada peserta didik untuk terlibat aktif sehingga konsep materi yang dipelajari benar-benar tertanam dan dikuasai dengan baik. Dalam hal ini bahan ajar berperan dalam menunjang aktifitas peserta didik di kelas, dimana bahan ajar yang dapat digunakan oleh guru adalah buku cetak dan LKS. Lembar Kerja Siswa (LKS) yang disajikan dengan melibatkan peserta didik secara aktif maka akan membantu guru untuk dapat lebih dekat dengan peserta didik akibat kegiatan-kegiatan yang dilakukannya.

Untuk meningkatkan keaktifan peserta didik dalam proses pembelajaran maka sebaiknya menggunakan LKS yang berhubungan dengan kehidupan sehari-hari peserta didik tersebut. Salah satu pendekatan pembelajaran matematika yang menghubungkan dengan kehidupan sehari-hari adalah pendekatan Realistic Mathematics Education. Selain itu struktur sajian materi matematika pada pembelajaran realistik diawali oleh realitas atau lingkungan, bahkan mungkin diawali dengan "matematika informal".

Karena LKS yang digunakan di MTs Masmur belum mendekatkan hubungan antara siswa dengan guru serta belum pernah menggunakan pendekatan $R M E$ kepada peserta didik dalam proses pembelajaran, untuk itu penelitian ini mengembangkan Lembar Kerja Siswa materi segitiga menggunakan pendekatan Realistic Mathematics Ediation yang betujuan untuk menghasilkan LKS yang valid dan praktis. Penelitian ini dilaksanakan di Kelas VII.2 MTs Masmur Pekanbaru.

Lembar Kerja Siswa (LKS) adalah bahan ajar yang dibuat guru agar dapat membantu peserta didik untuk memahami materi pelajaran dalam konteks yang 
PRINSIP Pendidikan Matematika

Volume 1, Nomor 1, November 2018

simple dan ringkas disertai dengan tugas-tugas untuk melatih peserta didik. Penyusunan lembar kerja siswa dapat berpedoman pada petunjuk sebagai berikut: 1) Sesuai dengan ruang lingkup materi pembelajaran yang dipelajari; 2) Perintah mengerjakannya disusun dengan menggunakan bahasa yang jelas mudah dipahami; 3) Isi perintah bersifat dorongan untuk meningkatkan kemampuan dan mengundang rasa ingin tahu peserta didik; 4) Berkaitan dengan sumber belajar yang ada disekitarnya; 5)Menekan pada kemampuan yang berkaitan dengan keterampilan proses.

$R M E$ adalah suatu pendekatan pembelajaran matematika yang menekankan bahwa matematika itu bukan suatu yang abstrak, matematika dapat dibayangkan dan dapat diaplikasikan oleh siswa dalam kehidupan sehari-hari dengan konsep formal matematika. (Tarigan, 2006) dalam pembelajaran matematika realistik dimulai dari masalah yang real sehingga peserta didik dapat terlibat dalam proses pembelajaran secara bermakna. Peran guru terutama sebagai pembimbing dan fasilitator bagi peserta didik. Treffers dalam (Wijaya, 2012) merumuskan lima karakteristik RME, yaitu: Penggunaan konteks, Penggunaan model untuk matematisasi progresif, Pemanfaatan hasil kontruksi siswa, Interaktivitas dan Keterkaitan. Pengembangan Lembar Kerja Siswa dengan Pendekatan Realistic Mathematics Education

Berdasarkan Kurikulum Tingkat Satuan Pendidikan (KTSP) tahun 2006, materi yang diambil untuk mengembangkan LKS oleh peneliti adalah materi segitiga dengan Standar Kompetensi, Kompetensi Dasar dan Indikator dibawah ini:

Tabel 1. Standar Kompetensi, Kompetensi Dasar, dan Indikator Penelitian

\section{Standar Kompetensi: Memahami konsep segiempat dan segitiga serta menentukan} ukurannya

\begin{tabular}{ll}
\multicolumn{1}{c}{$\begin{array}{c}\text { Kompetensi } \\
\text { Dasar }\end{array}$} & \multicolumn{1}{c}{ Indikator } \\
\hline 6.1. Meng & Siswa menyimpulkan pengertian \\
identifikasi & segitiga \\
sifat-sifat & Siswa dapat membedakan jenis- \\
segitiga & jenis segitiga berdasarkan sisi dan \\
berdasarkan & sudut \\
sisi dan & Menentukan sudut dalam segitiga \\
sudutnya & Menentukan sudut luar segitiga \\
6.2. Menghitun & Menurunkan luas dan keliling \\
g keliling dan & segitiga \\
\hline
\end{tabular}

luas 6.3. bangun yang berkaitan dengan segitiga dan menghitung keliling dan luas segiempat serta segitiga menggunakann ya dalam pemecahan masalah

\section{METODE}

Bentuk penelitian yang dilakukan adalah penelitian pengembangan dengan istilah Research \& Development $(R \& D)$. Menurut Sugyiono, 2014 menyatakan bahwa langka-langkah penelitian pengembangan $R \& D$ meliputi: (1) identifikasi masalah; (2) pengumpulan informasi; (3) desain produk; (4) validasi desain; (5) perbaikan desain; (6) uji coba produk; (7) revisi produk; (8) uji coba pemakaian; (9) revisi produk tahap akhir; dan (10) prosuksi massal. Penelitian ini dilaksanakan MTs Masmur Pekanbaru semester genap tahun ajaran 2014/2015. Subjek penelitian adalah siswa kelas VII.2 MTs Masmur Pekanbaru yang terdiri dari 23 orang siswa.

Instrumen penelitian yang dikembangkan menggunakan angket dimana angket yang digunakan adalah angket tertutup. Menurut Riduwan, 2007 mengatakan bahwa angket tertutup adalah angket yang disajikan dalam bentuk sedemikian rupa sehingga responden diminta untuk memilih satu jawaban yang sesuai dengan karakteristik dirinya dengan cara memberikan tanda silang (x) atau tanda checklist $(\sqrt{ })$. Sehingga untuk mengumpulkan data dalam penelitian ini menggunakan:

1. Lembar Validasi/Angket Validasi yang diisi oleh pakar (expert) dan teman sejawat (guru), berisikan validasi isi (content), konstruk dan bahasa.

2. Lembar Praktikalitas, yang terbagi menjadi 3, yaitu:

a. Angket respon guru terhadap praktikalitas LKS

b. Angket respon siswa terhadap Praktikalitas LKS

c. Angket keterlaksanaan dalam proses pembelajaran menggunakan LKS

Teknik analisis yang digunakan adalah analisis deskriptif yang mendiskripsikan validitas dan kepraktisan lembar kerja siswa dengan pendekatan RME. 
PRINSIP Pendidikan Matematika

Volume 1, Nomor 1, November 2018

1. Analisis validitas lembar kerja siswa dengan pendekatan RME.

Data yang dikumpulkan dari penelitian ini adalah hasil validasi LKS oleh tim ahli yang dianalisis menggunakan analisis kuantitatif. Dimana interval penilaian menggunakan skala likert, menurut (Sugiyono, 2014) Skala likert mempunyai gradasi dari sangat positif sampai sangat negatif. Peneliti berpedoman pada skala likert seperti tabel dibawah ini.

Tabel 2. Skala Penilaian dan Kategorinya

\begin{tabular}{cc} 
Skor Penilaian & Kategori \\
\hline 4 & Sangat Baik \\
3 & Baik \\
2 & Kurang Baik \\
1 & Tidak Baik \\
\hline
\end{tabular}

(Sumber: Modifikasi Skala Likert)

Dimana untuk mencari nilai setiap validator maka peneliti menggunakan rumus sebagai berikut:

$$
\text { Nilai }=\frac{\sum \text { skor yang diperoleh }}{\text { skor } \begin{array}{c}
\text { maksimun } \times \text { banyak item } \\
\times 100 \%
\end{array}}
$$

Sehingga untuk mengetahui nilai validator secara keseluruhan, maka meneliti menggunakan rumus rata-rata, yaitu

$$
\bar{V}=\frac{\sum \text { nilai setiap validator }}{n}
$$

Ketetangan:

$\bar{V} \quad$ = validitas rata-rata

$n$ = banyak validator

$\Sigma=$ jumlah

Hasil validitas rata-rata setelah diketahui, maka penilaian validitas dapat mengacu pada kriteria:

Tabel 3. Kriteria Penilaian Validitas

\begin{tabular}{cc}
\hline Kriteria Validitas & $\begin{array}{c}\text { Tingkat } \\
\text { Validitas }\end{array}$ \\
\hline $85,01 \%-100 \%$ & Sangat valid \\
$70,01 \%-85 \%$ & Cukup valid \\
$50,01 \%-70 \%$ & Kurang valid \\
$1 \%-50 \%$ & Tidak valid \\
\hline
\end{tabular}

Sumber:(Akbar, 2013)

2. Analisis praktikalitas lembar kerja siswa dengan pendekatan $R M E$

Dalam hal ini peneliti menyebarkan tiga angket, yaitu angket respos guru, angket respon siswa, dan angket keterlaksanaan. Dimana interval penilaian menggunkan skala likert, menurut (Sugiyono, 2014) Skala likert mempunyai gradasi dari sangat positif sampai sangat negatif. Peneliti menggunakan skala likert seperti tabel 2.

Dimana untuk mencari nilai setiap angket dingunakan rumus di bawah ini.

Nilai

$$
=\frac{\sum \text { skor yang diperoleh }}{\text { skor maksimun } \times \text { banyak item penilaian }}
$$

Sehingga untuk mengetahui nilai praktikalitas secara keseluruhan, maka peneliti menggunakan rumus rata-rata, yaitu

$$
\bar{P}=\frac{\sum \text { nilai setiap angket }}{n}
$$

Ketetangan:

$$
\begin{aligned}
\bar{P}= & \text { praktikalitas rata-rata } \\
n= & \text { banyak angket } \\
\Sigma= & \text { jumlah } \\
& \text { Hasil praktikalitas rata-rata setelah diketahui, }
\end{aligned}
$$
maka penilaian praktikalitas dapat mengacu pada kriteria:

Tabel 4. Kriteria Penilaian Praktikalitas

\begin{tabular}{cc}
\hline Kriteria Praktikalitas & $\begin{array}{c}\text { Tingkat } \\
\text { Validitas }\end{array}$ \\
\hline $85,01 \%-100 \%$ & Sangat praktis \\
$70,01 \%-85 \%$ & Cukup praktis \\
$50,01 \%-70 \%$ & Kurang praktis \\
$1 \%-50 \%$ & Tidak praktis \\
\hline
\end{tabular}

Sumber:Modifikasi dari (Akbar, 2013)

\section{HASIL DAN PEMBAHASAN}

Kegiatan validasi ini berlangsung mulai dari 28 Februari-14 Maret 2015. Dimana kegiatan tersebut bertujuan untuk mengetahui kejelasan isi dan kebermaknaan gambar yang dapat membimbing siswa. Selanjutnya produk pertama divalidasi oleh tim ahli, sehingga hasil validasi dari produk awal dapat dilihat pada tabel berikut:

Tabel 5. Masukan dan Hasil Revisi Produk Awal

\begin{tabular}{lll}
\hline & \multicolumn{1}{c}{ Masukan } & \multicolumn{1}{c}{ Hasil Revisi } \\
\hline & $\begin{array}{l}\text { Gambar } \\
\text { pastel tidak } \\
\text { cocok lagi } \\
\text { karena sudah } \\
\text { banyak yang } \\
\text { menggunaka }\end{array}$ & $\begin{array}{l}\text { Menganti gambar } \\
\text { gambar kotak kad }\end{array}$ \\
& dan tanda kendaraan \\
&
\end{tabular}


PRINSIP Pendidikan Matematika

Volume 1, Nomor 1, November 2018

\begin{tabular}{|c|c|c|}
\hline & $\begin{array}{l}\text { n gambar } \\
\text { tersebut }\end{array}$ & \\
\hline 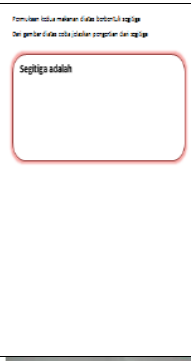 & $\begin{array}{l}\text { Siswa tidak } \\
\text { tahu cara } \\
\text { menuliiiskan } \\
\text { pengertian } \\
\text { segitiga }\end{array}$ & $\begin{array}{l}\text { Membuat petanyaan } \\
\text { berupa jumlah sisi } \\
\text { dan jumlah } \\
\text { sudutnya. Sehingga } \\
\text { siswa dapat } \\
\text { membuat pengertian } \\
\text { segitiga berdasarkan } \\
\text { sisi dan sudut }\end{array}$ \\
\hline & $\begin{array}{l}\text { Gambar tali } \\
\text { yang difoto } \\
\text { tidak } \\
\text { menunjukka } \\
\text { n jarak yang } \\
\text { sama }\end{array}$ & $\begin{array}{l}\text { Mengulang foto } \\
\text { kembali dengan } \\
\text { meluruskan tali }\end{array}$ \\
\hline 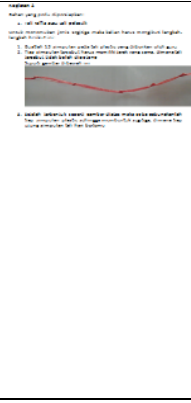 & $\begin{array}{l}\text { Perintah } \\
\text { untuk setiap } \\
\text { kegiatan } \\
\text { dengan } \\
\text { menggunaka } \\
\text { n tali plastik } \\
\text { masih } \\
\text { membinggun } \\
\text { gkan siswa } \\
\end{array}$ & $\begin{array}{l}\text { Setiap kegiatan } \\
\text { disertai dengan } \\
\text { gambar }\end{array}$ \\
\hline - & $\begin{array}{l}\text { Mengggunak } \\
\text { an gambar } \\
\text { segitiga sama } \\
\text { sisi saja } \\
\text { kurang baik, } \\
\text { dan } \\
\text { menemukan } \\
\text { jumlah sudut } \\
\text { dalam } \\
\text { segitiga } \\
\text { dengan } \\
\text { menggunaka } \\
\text { n busur tidak } \\
\text { akurat }\end{array}$ & $\begin{array}{l}\text { Meminta setiap } \\
\text { kelompok } \\
\text { menggambarkan } \\
\text { segitiga yang } \\
\text { berbeda, dan } \\
\text { menemukan jumlah } \\
\text { sudut dalam segitiga } \\
\text { dengan cara } \\
\text { menggambungkan } \\
\text { potongan dua buah } \\
\text { sudut yang digunting } \\
\text { sehingga } \\
\text { membentuk sudut } \\
\text { pelurus }\end{array}$ \\
\hline Pixy & $\begin{array}{l}\text { Kegiatan } 4 \\
\text { masih } \\
\text { membinggun } \\
\text { gkan siswa } \\
\text { karena belum } \\
\text { mengetahui } \\
\text { konsep untuk } \\
\text { menentukan } \\
\text { besar sudut } \\
\text { luar segitiga }\end{array}$ & $\begin{array}{l}\text { Pada kegiatan } 4 \\
\text { dilakukan penemuan } \\
\text { konsep terlebih } \\
\text { dahulu dan } \\
\text { menyusun kalimat } \\
\text { realistik tersebut } \\
\text { menjadi beraturan. }\end{array}$ \\
\hline
\end{tabular}

\begin{tabular}{|c|c|c|}
\hline 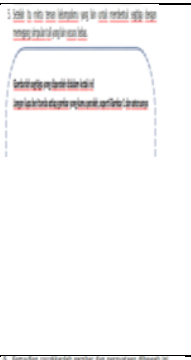 & $\begin{array}{l}\text { Menggambar } \\
\text { kan segitiga } \\
\text { sebanyak } \\
\text { berapa kali? }\end{array}$ & $\begin{array}{l}\text { Menambah langkah- } \\
\text { langkah kegiatan } \\
\text { untuk mengulang } \\
\text { langkah 3-5 sebnyak } \\
3 \text { kali dan } \\
\text { menyediakan kotak } \\
\text { untuk setiap } \\
\text { gambarnya }\end{array}$ \\
\hline$=\cong$ & $\begin{array}{l}\text { Pada LKS } \\
\text { kegiatan } 1 \\
\text { diperintahkan } \\
\text { untuk } \\
\text { mencocokka } \\
\text { n. Kata } \\
\text { mencocokka } \\
\text { n masih } \\
\text { membinggun } \\
\text { gkan }\end{array}$ & $\begin{array}{l}\text { Kata mencocokkan } \\
\text { itu lanjutkan dengan } \\
\text { kata menggunakan } \\
\text { diagram panah }\end{array}$ \\
\hline$=$ & $\begin{array}{l}\text { Alat yang } \\
\text { harus } \\
\text { disediakan } \\
\text { tidak sesuai } \\
\text { dengan isi } \\
\text { kegiatan }\end{array}$ & $\begin{array}{l}\text { Memasukkan semua } \\
\text { alat yang digunakan } \\
\text { didalam daftar alat } \\
\text { yang diperlukan }\end{array}$ \\
\hline & $\begin{array}{l}\text { Gambar garis } \\
\text { merah pada } \\
\text { kegiatan } 2 \\
\text { LKS } 2 \text { tidak } \\
\text { menyatakan } \\
\text { sgambar } \\
\text { dipotong }\end{array}$ & $\begin{array}{l}\text { Memotong gambar } \\
\text { tersebut sehingga } \\
\text { kelihatan } \\
\text { perpisahannya dan } \\
\text { memberikan no di } \\
\text { setiap potongan }\end{array}$ \\
\hline 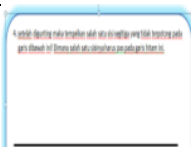 & \multirow{2}{*}{$\begin{array}{l}\text { Kegiatan } \\
\text { untuk } \\
\text { menempel } \\
\text { potongan } \\
\text { kertas } \\
\text { tersebut tidak } \\
\text { jelas }\end{array}$} & \multirow{2}{*}{$\begin{array}{l}\text { Menuliskan cara } \\
\text { menempel dengan } \\
\text { urutan nomor } \\
\text { potongan ujung } \\
\text { segitiga }\end{array}$} \\
\hline$=$ & & \\
\hline
\end{tabular}

Selain menggunakan komentar peneliti juga memberikan angket validasi yang berisikan pertanyaan sebanyak 11 poin dengan skor maksimumnya adalah 4 sehingga pada produk pertama ini diperoleh bahwa untuk tim ahli 1 berjumlah 28 , untuk tim ahli 2 berjumlah 27, untuk tim ahli 3 berjumlah 25 dan untuk tim ahli 4 berjumlah 25 . Sehingga dengan menggunalakan rumus nilai untuk tim ahli 1 diperoleh Nilai 63,64\%, tim ahli $261,36 \%, 56,82 \%$, dan untuk tim ahli $456,82 \%$. Sehingga diperoleh rata-rata 
validasi pada produk awal 59,66\% yang termasuk pada kategori kurang valid. Hasil validasi pada produk awal selanjutnya dijadikan sebagai bahan revisi, sehingga menghasilkan produk hasil revisi. Setelah dilakukan revisi, maka hasil produk revisi tersebut diberikan kepada 4 orang tim ahli untuk dilakukan proses validasi ke dua.

Sama seperti validasi pertama, dimana pada validasi keduai ini peneliti juga memberikan angket validasi yang berisikan pertanyaan sebanyak 11 poin dengan skor maksimumnya adalah 4 sehingga pada produk kedua ini diperoleh bahwa untuk tim ahli 1 berjumlah 29 , untuk tim ahli 2 berjumlah 40 , untuk tim ahli 3 berjumlah 33 dan untuk tim ahli 4 berjumlah 36 . Sehingga dengan menggunalakan rumus nilai untuk tim ahli 1 diperoleh Nilai 65,91\%, tim ahli 2 90,91\%, tim ahli 3 75\%, dan untuk tim ahli 4 81,82\%. Sehingga diperoleh rata-rata validasi kedua ini $78,41 \%$ yang termasuk pada kategori cukup valid.

Pada proses praktis peneliti mengambil data dari angket respon siswa, respon guru, dan angket keterlaksanaan. Dimana ketiga angket tersebut diolah perdasarkan setiap pertemuan yang dapat dilihat pada Gambar 1 di bawah ini.

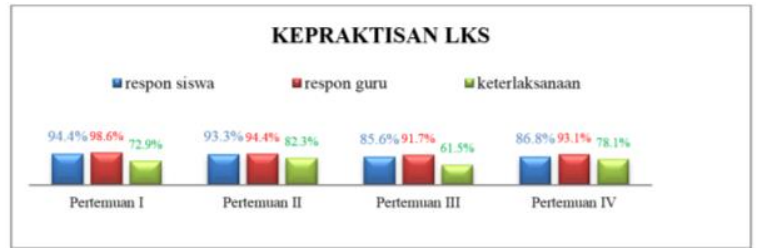

Gambar 1. Data Kepraktisan LKS

Dari keempat pertemuan diatas maka diperoleh nilai rata-rata kepraktisan LKS untuk setiap pertemuan berdasarkan hasil dari angket respon siswa, angket respon guru dan angket keterlaksanaan, maka diperolehlah data seperti pada gambar di bawah ini.

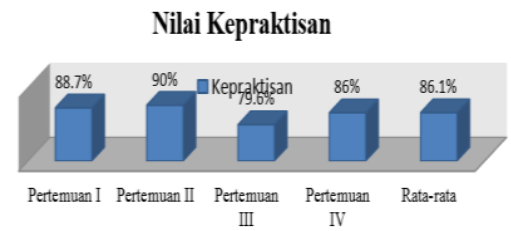

Gambar 2. Nilai Kepraktisan

Dari gambar diatas maka dapat dinyatakan bahwa untuk LKS materi segitiga tersebut memperoleh nilai $86,1 \%$ yang berada pada katagori Sangat Praktis. Kelemahan Penelitan
Berdasarkan hasil penelitian yang dilkukan di MTs Masmur Pekanbaru pada kelas VII.2 maka peneliti menemukan beberapan kendala atau kelemahankelemahan yang terjadi selama proses pembelajaran. Kelemahan-kelemahan yang terjadi antara lain:

1. Waktu yang diperlukan dalam menyelesaikan LKS terlalu singkat sehingga LKS tidak terjawab secara keseluruhan

2. Kurang terjadinya proses pembelajaran dengan pendekatan $R M E$ dikarenakan guru yang tetap pada metode pembelajaran yang biasa dipakai sehari-hari. Sehingga kegiatan pembelajaran tidak sesuai dengan RPP yang dibuat oleh peneliti.

3. Siswa mengisi angket secara asal-asalan saja sehingga menghasilkan nilai yang tidak sesuai dengan keadaan yang terjadi didalam kelas.

\section{SIMPULAN}

Berdasarkan hasil pembahasan dan penelitian maka dapat disimpulkan bahwa LKS pada materi segitiga dengan pendekatan Realistic Mathematics Education untuk kelas VII SMP/MTs dinyatakan valid dan praktis pada siswa kelas VII.2 MTs Masmur Pekanbaru.

\section{DAFTAR PUSTAKA}

Akbar, S. (2013). Instrumen Perangkat Pembelajaran. Bandung: PT. Remaja Rosdakarya.

Misdalina, Zulkardi, \& Purkowo. (2009). Pengembangan Materi Integral untuk SMA Menggunakan Pendekatan Pendidikan Matematika Realistik Indonesia di Palembang. Jurnal Pendidikan Matematika; Volume 3 No 1 Juni 2009, hal. 54. Palembang: Program Studi Pendidikan Matematika Program Pascasarjana UNSRI.

Riduwan. (2007). Belajar Mudah Penelitian untuk Guru, Karyawan dan Peneliti Pemula. Bandung: Alfabeta.

Sugiyono. (2014). Metodologi Penelitian Pendidikan Pendekatan Kuantitatif, Kualitatif, dan R\&D. Bandung: Alfabeta

Susanto, A. (2010). Teori Belajar \& Pembelajaran di Sekolah Dasar. Jakarta: Kencana 
PRINSIP Pendidikan Matematika

Volume 1, Nomor 1, November 2018

Tarigan, D. (2006). Pembelajaran Matematika Realistik. Jakarta: Departemen Pendidikan Nasional Direktorat Jendral Pendidikan Tinggi.
Wijaya, A. (2012). Pendidikan Matematika Realistik. Yogyakarta: Graha Ilmu 